\title{
Informationskompetence, en opgave for bibliotek og uddannelse i fællesskab
}

\author{
Mette Bønløkke, lektor og studiekoordinator, VIA Universty College \\ Else Kobow, lektor, VIA Universty College
}

Anne-Kirstine Kristensen, bibliotekar, VIA Bibliotekerne

\section{Reviewet artikel}

\begin{abstract}
Erfaringer og undersøgelser om samarbejde mellem uddannelser og forskningsbiblioteker viser, at ikke alle har en curriculumintegreret indsats og et formaliseret samarbejde om undervisning og vejledning til støtte for udvikling af de studerendes informationskompetence. Et aktionsforskningsprojekt undersøgte, hvad der havde betydning i etablering af et formelt samarbejde mellem bibliotek og uddannelse. I projektet deltog tre bibliotekarer, seks undervisere og en biblioteksleder samt to uddannelsesledere og to projektledere fra VIA University College. Fokusgruppeinterviews, projektprotokoller, referater fra refleksions- og støttemøder samt mailkorrespondance udgjorde data, som blev kvalitativt analyseret. Resultaterne viste, at følgende områder er betydningsfulde: ledelsesstøtte, en anerkendende tilgang, oplevelse af nødvendighed og ejerskab til processen, fælles fokus og mål tilpasset den enkelte uddannelses behov, rammer og ressourcer, faglig støtte og erfaringsudveksling i processen.
\end{abstract}

\section{Indledning}

Erfaringer og undersøgelser om samarbejde med uddannelsesbiblioteker viser, at ikke alle uddannelser har et formaliseret samarbejde om undervisning og vejledning til støtte for udvikling af de studerendes informationskompetence (Moselen \& Wang, 2014). Samarbejdet ser meget forskelligt ud og er ofte uformelt. Nogle steder underviser bibliotekaren i informationssøgning uden sammenhæng med, hvad der foregår i uddannelsen, andre steder er underviser og bibliotekar sammen om vejledning i studerendes projekter.

Undersøgelser viser, at de studerende på videregående uddannelser har brug for støtte til at blive informationskompetente. Dette er en fælles opgave for bibliotekarer og undervisere (Bruce, 2004). Studerende fra bachelorniveau og opefter arbejder med teorier, metoder og praksis. De skal i stigende grad kunne anvende dette til at forstå og udvikle deres fag eller profession og i demonstration af akademisk kompetence. Informationskompetence er indeholdt i akademisk kompetence (Uddannelses- og forskningsministeriet , 2013; Rienecker \& Stray Jørgensen, 2012). 


\section{Hvad ved vi om informationskompetence \\ Informationskompetence kan defineres således:}

"To be information literate, a person must be able to recognize when information is needed and have the ability to locate, evaluate, and use effectively the needed information." (ACRL, 2014).

I litteraturen præciseres, at informationskompetence bør integreres i curriculum og knyttes til opgaver (Ford, Foxlee \& Green, 2009; Moselen \& Wang, 2014; Secker, 2011; Wang, 2010). Det betyder, at de studerende stilles opgaver med progredierende krav til informationskompetence uddannelsen igennem og udfordres på dette. Undersøgelser viser, at en curriculumintegreret indsats, hvor de studerendes indsats anerkendes, bevirker, at studerende bliver motiverede for at søge og inddrage ny viden i opgaver. (Bønløkke, Kobow \& Kristensen, 2012; Dixon-Thomas, 2012; Secker, 2011; Whitehurst, 2010). Ved curriculumintegrering er et samarbejde mellem bibliotek og uddannelse væsentligt. Tidspunkt og indhold i undervisning defineres i fællesskab, så progression i udvikling af informationskompetence sikres gennem uddannelsen. Der er desuden enighed om, at bibliotekaren skal ind i undervisningsrummet og have pædagogisk forståelse for, hvad der har betydning for de studerendes læring (Bønløkke et al., 2012; Dewey, 2004; Gibson \& Luxtin, 2009; Moselen \& Wang, 2014; Secker, 2011; Torras \& Sætre, 2009; Dale, 1989; Leth Andersen, 2009; McCluskey, 2010).

I udvikling af studerendes informationskompetence er der således behov for et tæt samarbejde mellem bibliotek og uddannelse, men dette kan være vanskeligt at etablere. Vores interesse var derfor at undersøge, hvad der har betydning i etablering af et formelt samarbejde mellem bibliotek og uddannelse. I forarbejdet til projektet lod vi os inspirere af teorier om implementering, aktionslæring og aktionsforskning (Duus, Husted, Kildedal, Laursen \& Tofteng, 2012; Hummelvoll \& Severinsson, 2005; Hummelvoll, 2006; Kotter, 1996; McNiff, 2013; Pålshaugen, 1991).

Formål med projektet blev at identificere vigtige og nødvendige elementer for etablering af et formelt samarbejde mellem bibliotek og uddannelse, hvor fokus var en curriculumintegreret indsats om udvikling af studerendes informationskompetence.

\section{Metode}

Aktionsforskning blev valgt som metode i projektet. Aktionsforskning har til formål at forandre og skabe ny viden. Metoden er kendetegnet ved at være refleksiv, fleksibel og processuel (Duus et al., 2012; Hummelvoll, 2006; Malterud, 2013). Aktionsforskning giver mulighed for en aktuel og meningsfuld intervention. Deltagerne skal være interesserede i at udvikle egen praksis og være parate til at deltage i en forandringsproces ved selv at formulere forandringerne, som her kaldes aktioner. Udviklingen sker gennem aktørernes læring og erfaringer (Kotter, 1996). Deltagerne kaldes aktører og bliver medforskere. Processen er baseret på dialog mellem alle involverede parter, hvorved der produceres ny viden i organisationen (Hummelvoll \& Severinsson, 2005; Pålshaugen, 1991). Forskerens rolle bliver at støtte refleksion og udvikling i processen samt dokumentere proces og udbytte (Duus et al., 2012; McNiff, 2013). 
Aktionsforskningsprocessen er en struktureret proces. Vi valgte med inspiration fra Hummelvoll og Pålshaugen en proces i 4 faser: forberedelse, orientering, intervention og evaluering (Hummelvoll \& Severinsson, 2005; Pålshaugen, 1991) (se figur 1). Projektet forløb fra januar til december 2013.

Figur 1 Forløbs og aktivitetsskema

Forløbs- og aktivitetsskema

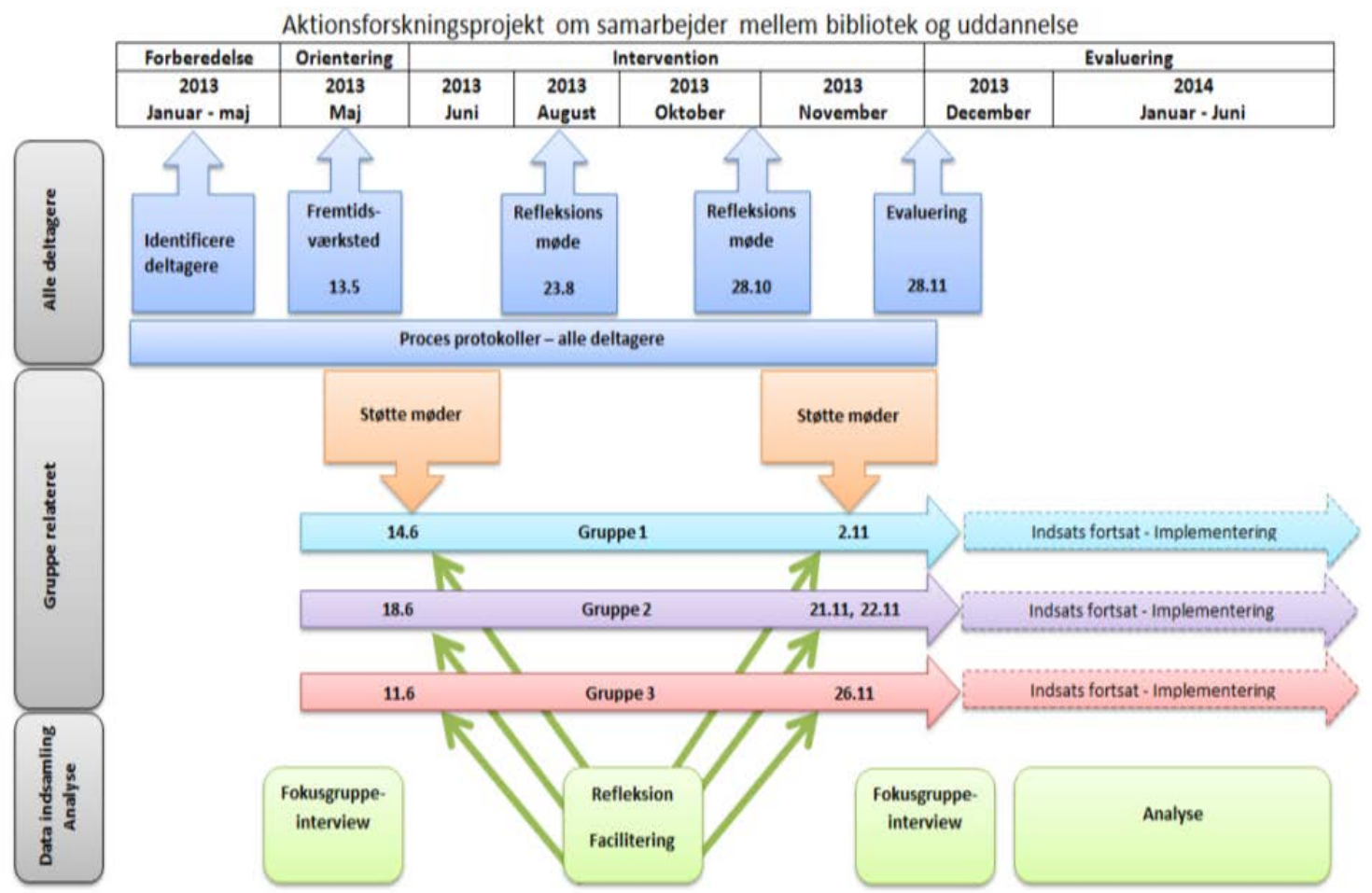

I fase 1 - forberedelse - identificerede vi til aktørerne til projektet. To VIA biblioteker meldte sig til deltagelse i projektet samt fire uddannelser, som disse biblioteker servicerede. Biblioteksledere og uddannelsesledere udpegede de personer, der skulle involveres i aktionerne. I alt deltog tre bibliotekarer og én biblioteksleder (én leder var inviteret men forhindret i at deltage) samt seks undervisere og to uddannelsesledere (begge leder for to uddannelser). Projektledelsen bestod af to lektorer. I denne fase blev alle enige om, at en curriculumintegreret indsats om udvikling af studerendes informationskompetence skulle være i fokus. Denne beslutning blev taget på baggrund af teorier og forskning om informationskompetence og indskrevet i formålet for projektet.

Fase 2 - orientering - startede med et fremtidsværksted (Duus et al., 2012; Jungk \& Müllert, 1989), hvor alle aktører og ledere deltog. Alle gav informeret samtykke til projektet (Kvale \& Brinkmann, 2009). Et fremtidsværksted skaber rum til at tænke kreativt og udviklende. Fremtidsværkstedet er en demokratisk proces, hvor alle bliver hørt og anerkendt. Et fælles fundament skabes (Duus et al., 2012; Jungk \& Müllert, 1989). Fremtidsværkstedet startede processen og gennem dialog formulerede aktørerne deres behov for en curriculumintegreret indsats. Aktørerne valgte at arbejde i tre grupper med tre forskellige aktioner, der passede til deres lokale behov. Gruppe 1 fokuserede på spredning af en curriculumintegreret indsats, der tidligere 
var beskrevet, men som ikke alle fulgte eller oplevede ejerskab til. Gruppe 2 var i færd med at implementere et nyt uddannelsestilbud og valgte samtidig at beskrive og implementere informationskompetence i curriculum. Gruppe 3 fokuserede på at etablere et bæredygtigt samarbejde mellem bibliotek og uddannelser, da samarbejdet hidtil havde været løst og uformelt. Umiddelbart efter fremtidsværkstedet afholdt vi det første fokusgruppeinterview for at indsamle baseline data om aktørernes oplevelse af informationskompetence, curriculumintegration, tidligere samarbejde samt oplevelser af fremtidsværkstedet. Fokusgruppeinterview blev udført af projektledelsen. Fokusgruppeinterview indsamler på kort tid mange og nuancerede data om, hvad mennesker tænker og hvorfor. Gruppeinteraktionen kan virke som inspiration og skabe en synergi, som uddyber data (Morgan, 1997). Moderator brugte interviewguide, observatøren tog noter. Interviewene blev optaget (Kvale \& Brinkmann, 2009). Aktørerne blev opfordret til at skrive procesprotokoller, der skulle afspejle deres tanker om og refleksioner over processen.

I løbet af fase 3 - intervention - afholdt vi 2 støttemøder med hver gruppe og 2 refleksionsmøder med alle aktører. I dialog delte aktører oplevelser og erfaringer, fik inspiration og udvekslede ideer (Hummelvoll \& Severinsson, 2005; Hummelvoll, 2006; Pålshaugen, 1991). Møderne blev optaget, og vi tog noter. Som projektledere støttede vi aktioner og faciliterede møder. Desuden skrev vi refleksioner over processen i procesprotokoller.

I den 4. og sidste fase - evaluering - afholdt vi det andet fokusgruppeinterview som en evaluering af processen. Alle optagelser blev udskrevet og slettes efter publicering af projektet. Udover transskriptioner af to fokusgruppeinterview, seks støttemøde og to refleksionsmøder indgik projektprotokoller og mailkorrespondance fra processen som data. Aktørerne valgte at skrive fælles procesprotokoller for hver gruppe, hvilket gav os tre procesprotokoller. Projektledelsens protokoller blev brugt som redskaber til at følge aktionerne, disse indgår ikke som data (Hummelvoll \& Severinsson, 2005). Data blev analyseret ved brug af en fænomenologisk-hermeneutisk tilgang: naiv læsning, struktureret analyse i tre trin: 1. "Hvad siger de", 2. "Hvad taler de om", 3. teksten struktureres i temaer og sub-temaer (Henricson, 2014; Kvale \& Brinkmann, 2009). For at sikre validitet i fortolkningen blev alt materiale gennemlæst af hver forfatter for sig og derefter kodet i temaer. Kodningen blev sammenlignet og diskuteret. Ved forskellig fortolkning vendte vi tilbage til data for at sikre, at den rette mening fremkom. Resultaterne fra kodningen blev sammenskrevet til tekst, under hensynstagen til den sammenhæng teksten oprindeligt indgik i, så overfortolkning kunne undgås. Denne tekst er præsenteret som resultater. Der var ekstern sparring på analyseprocessen og resultaterne fra vejleder samt refleksionspartner fra Aarhus University Library.

\section{Resultater}

Analysen resulterede i temaer, der belyste processens relevans, og hvad der fik betydning for etablering af samarbejdet på tværs af uddannelser og bibliotek (Tabel 1). Processens elementer fungerer som overskrifter i dette afsnit. Temaernes indhold er beskrevet og underbygget med illustrative citater fra data skrevet i kursiv. 
Tabel 1 Temaer fra analysen sammensat med processens elementer

\begin{tabular}{|l|l|}
\hline Processens elementer & Temaer fra analysen \\
\hline Udpege aktører & Ledelsesforankring \\
\hline Fremtidsværksted & Fremtidsværksted \\
\hline Formulere aktioner med aktørerne & Oplevelse af nødvendighed \\
& $\begin{array}{l}\text { Ejerskab } \\
\text { Fokus }\end{array}$ \\
\hline Refleksionsmøder & Støtte \\
& Erfarings- og vidensdeling \\
\hline Afprøve aktioner & Struktur og organisering \\
& Kulturforskelle \\
\hline Evaluere aktioner & Udbytte \\
\hline
\end{tabular}

\section{Udpege aktører}

Ledelsesforankring indgik som forudsætning for iværksættelse af et samarbejde på tværs. Lederne udpegede aktører, støttede arbejdet, tildelte og prioritererede ressourcer til arbejdet:

"Jeg synes jo, at det er vigtigt, at min leder siger, at der skal bruges nogle timer på det her." (B1).

"[...] Så det er alfa og omega, at man har ledelsesforankring, det er min oplevelse." (B2).

Lederens holdning fik betydning for aktionerne, når mål for implementering af udvikling af informationskompetence blev besluttet og ved godkendelse af dokumenter. Det var vigtigt, at lederen åbnede for diskussion og spredning i ledelseslaget.

\section{Fremtidsværksted}

Allerede ved invitationen til fremtidsværkstedet begyndte aktørerne at reflektere over problemstillinger vedr. informationssøgning og relevante aktioner. I fremtidsværkstedet blev det tydeligt for aktørerne, at de sad med de samme problemstillinger om udvikling af informationskompetence og implementering:

"Det er det samme, man står med i alle uddannelser." (U1). 
Fremtidsværkstedet gav anledning til at formulere sig, skabte en bevidsthed om et oplagt fokus, og gjorde aktionerne håndgribelige. Det blev klart for aktørerne, at bibliotekaren måtte have en stor viden om de enkelte uddannelser, og at underviseren skulle involvere sig i informationssøgning:

"Jeg synes også, jeg har fået en god indsigt i, hvor store krav det stiller til bibliotekaren. [...] I skal godt nok ind og vide noget om uddannelserne." (U2).

Refleksionerne i fremtidsværkstedet virkede positivt, da de tilgodeså et lokalt behov for udvikling.

\section{Formulere aktioner med aktørerne}

Dette element i processen viste, at oplevelse af nødvendighed, ejerskab og fokus havde betydning.

\section{Oplevelse af nødvendighed og ejerskab}

Aktørerne oplevede, at projektet kom på det rette tidspunkt. De var positive, velvillige, parate og tog opgaven på sig. Alle følte et behov for at gøre noget og oplevede manglende kvalitet i studerendes produkter:

"Der er tit tomme afsnit i deres litteratursøgning, når de afleverer deres projekter. Det har vi accepteret fordi [...] nåh ja, det kommer jo nok. Det skal vi væk fra!" (L1).

"Så der bliver en bevidsthed hos underviseren om, at som vejleder skal de udfordre de studerende på informationskompetence." (B2).

Man oplevede vigtigheden af, at hele kollegiet så nødvendigheden af aktionen og fik ejerskab til forandringerne, så en spredning i uddannelsen kunne ske:

"Man skal have alle undervisere med, alle skal have ejerskab. Alle skal sige god for det." (U1).

\section{Fokus}

Det var vigtig for aktørerne at have et relevant og konkret fokus at arbejde med. Selvom det var afgrænsede aktioner, oplevede de, at det fik indflydelse på hele uddannelsen - det bredte sig som ringe i vandet:

"Det er måske også det, at vi har haft et helt konkret fokus, så vi ville nå til ende med, ikke - og lukke - og blive enige om." (U3).

\section{Refleksionsmøder}

Temaerne fra refleksionsmøder drejede sig om støtte og erfarings- og videndeling.

Støtte

Det virkede støttende, når andre fulgte processen, stillede spørgsmål, delte viden og materialer. Man blev holdt fast. Ved den faglige sparring, oplevede aktørerne, at det 
var værdifuldt, at sparringspartnerne havde viden om informationskompetence og om processen. At sparringspartnerne var undervisere, betød en pædagogisk sparring og dermed en anden bundklang, end hvis aktionerne blev støttet af en person med biblioteksfaglig baggrund. Der var enighed om, at en sparrings- og refleksionspartner ikke måtte være lederen:

"I har meget mere viden om det specifikke, der foregår i det, vi har valgt at arbejde med, så har I også viden om informationssøgning [...] så I har kunnet stille nogle mere frække spørgsmål til os, end en leder ville have kunnet gøre." (B1).

Der var enighed om, at en sparrings- og refleksionspartner ikke måtte være lederen.

\section{Erfarings- og videndeling}

Uddannelserne havde fælles problemstillinger og kunne derfor inspirere hinanden:

"Jeg tænker også, at jo mere man sparrer tværfagligt, jo mere bliver man klar over de kompetencer, der ligger." (B1).

I de tværfaglige dialoger viste forskelligheder sig. Der var ikke kun én sandhed, der blev åbnet for diskussioner og gensidig inspiration:

"Der har været en gevinst ved, at det har været uddannelser på tværs, det er, at man kan se forskelligheder og kan blive inspireret af hinanden, der er flere sandheder end den ene. Før man italesætter det, så ved man jo ikke, hvad den enkelte tænker." (B3).

\section{Afprøve aktioner}

Dette element afspejlede oplevelser af arbejdsprocessen, struktur og organisering samt kulturforskelles betydning for processen.

\section{Struktur og organisering}

Aktørerne indså i forløbet, at et formelt forum for bibliotekar og underviser havde stor værdi. Dette forum havde til opgave at formulere og fastsætte mål, der tilgodeså uddannelsens struktur, de studerendes niveau og opgaver. Fysiske møder i processen var vigtige og inspirerende:

"Jeg synes, vi har kunnet bruge det (refleksionsmøderne) til noget, vi er også blevet inspireret af at høre, hvor i andre var i processen." (U4).

Det virkede forpligtende, at processen blev fulgt og faciliteret:

"Det er godt, at der er en tredje part til at facilitere processen, sætter noget andet i gang. Det er en fødselshjælper." (L2). 


\section{Kulturforskelle}

I processen opstod et behov for at diskutere og fortolke professionsbachelorniveauet i forhold til informationskompetence. Aktørerne oplevede, at kravene afhang af uddannelsesretningen læringsmål, uddannelses- og professionskultur:

"Det er lige præcist et eksempel på den der kulturforandring, vi skal have, for selvfølgelig er der ikke nogen, der kun må fokusere på at lave gode maskiner, ja, men de skal også vide, hvordan man laver et godt projekt." (U1).

Undervisernes forskellige fagligheder havde også betydning. Det fordrede bevågenhed og en eventuel kulturforandring i uddannelsen:

"Man skal ikke underkende, at vi har kulturen med os. Den lokale kultur og den professionelle kultur som sygeplejersker." (B2).

\section{Evaluere aktioner}

Aktionerne blev evalueret med aktørerne, så vi kunne udtale os om udbyttet af aktionerne og betydningen af samarbejdet på tværs af bibliotek og uddannelse. Gennem projektet blev samarbejdet mellem uddannelse og bibliotek øget og mere struktureret. Det styrkede relationerne og gav større kendskab til hinandens fagligheder og roller:

"Vi har selvfølgelig i forvejen et samarbejde, men det er blevet meget mere struktureret, og det har vi tænkt os at udbygge. Der er også kommet større klarhed over rollerne, altså bibliotekarens rolle og underviserens rolle, og det har givet rigtig meget." (U5).

"Vi er meget vant til, at det er personbundet, det der foregår, men hvorfor er det ikke fælles, også for at lave kvalitetssikring på, så der rent faktisk er overensstemmelse mellem, hvad den ene og den anden vejleder siger". (B3).

Bibliotekarerne udtrykte, at kendskab til uddannelsen gav større overblik over deres bidrag til de studerendes udvikling af informationskompetence. Underviserne fik en øget bevågenhed på informationskompetence generelt:

"Nu er det et samarbejde med dem, der faktisk står og underviser, og det tænker jeg da er en klar forbedring, vi får indholdssiden i spil på en helt anden måde." (B2).

Der var enighed om, at informationskompetence måtte formuleres i uddannelsesdokumenter.

\section{Diskussion}

I aktionsforskning afhænger resultaterne fuldstændigt af aktørerne, som medvirker som medforskere (Duus et al., 2012; Hummelvoll, 2006; McNiff, 2013). Vores aktører var velvalgt af lederne. Havde de ikke været så engagerede og aktive i processen, 
ville det have fået stor betydning for kvalitet og nuancering af projektets resultater. Deres professionalitet og interesse skabte en synergieffekt, der berigede alle i processen og skabte viden om, hvad der har betydning for et samarbejde mellem bibliotek og uddannelse. Vi var noget bekymrede for, om aktørerne ville tage projektet til sig og gøre det til deres, hvilke var en af grundene til at aktionsforskning blev valgt som metode. Denne bekymring var overflødig, som en aktør formulerede det: "Det er absolut mit projekt - eller vores - det er ikke jeres." (B3).

Vi havde forventet, at aktørerne skrev projektprotokoller, da der var givet timer til det i projektet. Dette skete ikke, der blev skrevet en fælles protokol for hver af grupperne, som beskrev proces og produkter mere end refleksioner over processen. Refleksionerne indgik alligevel som data, da de fremkom på møderne og blev fastholdt i optagelserne af disse.

Aktørernes positive holdning til projektet og deres aktioner gjorde, at der ikke viste sig kritiske røster i forhold til forløbet, selvom det blev efterspurgt på møderne og til evalueringen. Kritiske røster giver nye perspektiver på det, der sker, og er med til at udvikle processen (McNiff, 2013). Vores eksterne sparringspartner og vejleder fungerede til gengæld som kritiske røster og var med til at validere analysen ved at udfordre os og vores distance til data (Kvale \& Brinkmann, 2009). Datamængden blev stor og kom fra forskellige kilder, hvilket gav os adgang til aktørernes tanker i og om processen såvel som deres personlige teorier om deres professionelle praksis. Faren for overfortolkning i analyseprocessen søgte vi minimeret ved at analysere hver for sig og få ekstern sparring (Kvale \& Brinkmann, 2009).

Fremtidsværkstedets tre faser - kritik-, utopi- og virkelighedsgørelsesfasen (Duus et al., 2012; Jungk \& Müllert, 1989) - startede projektet og sikrede ejerskab og et fælles fokus for aktionerne. Aktørerne fik en positiv oplevelse af, at de havde fælles udfordringer. Det tyder på, at et fremtidsværksted kan være en værdifuld måde at starte et samarbejde på, når man kommer fra forskellige faglige sammenhænge - uddannelse og bibliotek - og skal finde et fælles fokus. Andre innovative og kreative processer som fx Appreciative Inquiry har ikke en kritisk fase. Det kan diskuteres, om det er en fordel at kritisere tingenes tilstand, når man gerne vil arbejde positivt, konstruktivt med ønsker for fremtiden. Kritikpunkter og frustrationer får en stemme, men ideen er, at man herved lægger dem bag sig (Duus et al., 2012), hvilket vi så i projektet.

Vi valgte, at lederne deltog fra første færd. De godkendte projektet og pegede på aktører til projektet. Bruce (Bruce, 2004) påpeger, hvor betydningsfuldt det er, at hele organisationen støtter bestræbelser om at udvikle informationskompetence hos de studerende, og her er lederen vigtig. Igennem hele projektet mærkede vi et ledelsesmæssigt engagement og en opmærksomhed på processen. Som leder er man ansvarlig for at formulere og kommunikere visioner og strategier. Lederne er dem, der afsætter ressourcer og spreder viden på deres niveau og i organisationen (Kotter, 1996). I projektet fik dette betydning for aktionernes mulighed for imple- 
mentering og spredning i organisationen. I projektet var lederne tæt på uddannelsen, men spørgsmålet er, om det altid er muligt - afhængig af deres ledelsesopgaver.

Et uformelt samarbejde er personafhængigt og overlever på det. Det er dynamisk og fleksibelt. En formel struktur skaber kontinuitet, stabilitet og gennemsigtighed og giver bedre mulighed for at skabe, dele og forankre nye initiativer $\mathrm{i}$ en institution (Waldstrøm, 2013). Aktionsprocessen satte en ramme for samarbejdet og forpligtede aktørerne på at mødes. Resultaterne peger på, at et formaliseret samarbejde er nødvendigt.

Indlejret i processen var støtte- og refleksionsmøder. Ofte er forskningslederen en novice inden for det felt, der undersøges (Hummelvoll, 2006), men ikke i dette projekt, hvilket fik betydning for aktørernes oplevelse. Det var betydningsfuldt, at en person med relevant faglig viden fulgte processen. En faglig sparringspartner kan udfordre og støtte den læringsproces og udvikling, der foregår i aktionerne (Duus et al., 2012; Pettersen, 1997). I en aktionsforskningsproces er det afgørende, at projektlederen anerkender gruppen og de enkelte gruppemedlemmer ud fra deres ståsted, og hvad de har behov for at arbejde med (Duus et al., 2012; McNiff, 2013). Gennem fremtidsværkstedet fik projektledelsen viden om, hvordan samarbejdet tidligere havde været samt den enkelte uddannelses og det enkelte biblioteks vilkår og ståsted. Det var vigtigt at få gruppens tanker om informationskompetence og uddannelse belyst for at kunne støtte og anerkende deres proces (Duus et al., 2012).

I processen var ejerskab tænkt indlejret. Aktørerne havde fra starten oplevet nødvendigheden af at få diskuteret og arbejdet med informationskompetence. At udvikle noget konkret til uddannelsen var medvirkende til at føle ejerskab. Samtidig sås nødvendigheden af, at den indsigt, der var fremkommet, blev spredt i organisationen, så alle blev involveret, og en reel værdi i uddannelsen blev skabt (Kirketerp \& Greve, 2011). Processen var tværfaglig, da fagfolk fra bibliotek og uddannelse indgik i processen. Denne tværfaglighed syntes at være en gevinst: Den styrkede refleksionerne, og der opstod en bevidsthed om ligheder og forskelligheder, der blev brugt konstruktivt. På trods af de helt forskellige udfordringer i uddannelserne, blev det tydeligt, at der var fælles ambitioner om at udvikle de studerendes informationskompetence tilpasset den enkelte uddannelse. I løbet af de seks måneder projektet varede opstod en bevidsthed om, at integration af informationskompetence i curriculum kunne betyde en kulturændring for såvel bibliotek som for uddannelse. En sådan kulturændring griber forandrende ind i hverdagens arbejde og kræver involvering og kommunikation om ændringsprocessen (Kirketerp \& Greve, 2011; Kotter, 1996).

Indbyrdes opstod en større forståelse af aktørernes roller i udvikling af de studerendes informationskompetence og betydning af bibliotekarens kendskab til uddannelsen. Processen var et kulturelt møde, hvor aktørerne bragte deres kultur og selvforståelse med. I mødet og dialogen udviklede de sig og så nye muligheder (Hastrup, Rubow \& Tjørnhøj-Thomsen, 2011). De nye opfattelser og perspektiver fik en positiv 
betydning og bevågenhed i samarbejdet mellem bibliotek og uddannelse. Aktørerne havde tilkendegivet interesse for at deltage i projektet, dette kan have farvet resultaterne $\mathrm{i}$ en positiv retning. Samtidig havde alle aktørerne en klar tillid til deres egne faglige kompetencer, hvilket i sig selv var med til at skabe motivation og handlekraft.

Processen viste, at den struktur, der var lagt ned over projektet med ledelsesforankring, fremtidsværksted, støtte- og refleksionsmøder, var befordrende for etablering af det formelle samarbejde. Samtidig skulle det, der blev arbejdet med have relevans lokalt. Projektet viste, at processen fungerede uanset uddannelse og bibliotek og uanset graden af tidligere curriculumintegration af informationskompetence. Set i lyset af den store informationsmængde studerende på alle niveauer i uddannelsessystemet skal forholde sig til, må de nødvendigvis lære at søge, sortere, vurdere og anvende informationer. Processen forløb i regi af professionsbacheloruddannelser. Vi formoder derfor, at en lignende proces vil kunne anvendes andre steder i uddannelsessystemet, hvor man ønsker, at de studerende udvikler informationskompetence, og hvor man ønsker at etablere et velfungerende samarbejde herom på tværs af bibliotek og uddannelser.

\section{Konklusion}

I etablering af et samarbejde mellem bibliotek og uddannelse synes det vigtigt, at der er ledelsesopbakning til samarbejdet, at informationskompetence opleves vigtigt og prioriteres, og at ressourcer følger med til samarbejdet. Et fælles afsæt, som fx et fremtidsværksted, er betydningsfuldt for at identificere fokus for samarbejdet og for relationen i det tværfaglige samarbejde. Faste rammer og faglig støtte i etableringen af samarbejdet opleves betydningsfuldt. Ejerskab til processen hos bibliotekar og underviser, og at der er lokal forankring i forhold til den enkelte uddannelses behov, er vigtigt. Et formaliseret samarbejde giver indsigt i hinandens kultur og faglighed og en bevidsthed om kompetencer og roller i udvikling af de studerendes informationskompetence.

En stor tak til deltagerne i projektet fra VIA bibliotekerne i Horsens og Silkeborg, VIA Sygeplejerskeuddannelsen i Horsens og Silkeborg samt VIA Mechanical Engineering og VIA Global Business i Horsens. Desuden takker vi for økonomisk støtte fra Danmarks Elektroniske Fag- og Forskningsbibliotek, Kulturstyrelsen og VIA Sundhed.

Mette Bønløkke, sygeplejerske, SD i Uddannelse og Undervisning, MPH. Ansat som lektor og studiekoordinator på VIA Sygeplejerskeuddannelsen i Silkeborg, Campus Silkeborg. Underviser i folkesundhedsvidenskab og metodologi. Arbejder desuden som proceskonsulent og med internationalisering. Har siden 2006 arbejdet med udvikling af de studerendes informationskompetence i projekter og publiceret artikler samt et lærebogskapitel om dette.

Else Kobow, sygeplejerske, SD i Uddannelse og Undervisning, cand.cur. Ansat som lektor på VIA Sygeplejerskeuddannelsen i Silkeborg, Campus Silkeborg. Ansat som underviser ved Sygeplejerskeuddannelsen i Silkeborg siden 1990. Underviser i sygepleje inden for fagområderne fortælling, profession, forskning og udvikling, egenomsorg og omsorg, 
body-image, rehabilitering og mestring. Har siden 2006 arbejdet med udvikling af de studerendes informationskompetence i projekter og publiceret artikler om dette.

Anne-Kirstine Kristensen, bibliotekar. Ansat som bibliotekar ved VIA Bibliotekerne, Biblioteket Campus Silkeborg. Underviser og vejleder i informationssøgning og referencehåndtering. Støtte til VIAs forsknings- og udviklingsaktiviteter. Har siden 2002 arbejdet med udvikling af de studerendes informationskompetence, samt deltaget i flere projekter om informationskompetence.

\section{Litteratur}

ACRL (2014). Information literacy competency standards for higher education / association of college \& research libraries (ACRL). Retrieved from http://www.ala.org/acrl/standards/informationliteracycompetency\#ilhed

Bønløkke, M., Kobow, E. \& Kristensen, A. (2012). Curriculum integrated information literacy: A challenge. Vård i Norden, 32(3), s. 53-55.

Bruce, C. (2004). Information literacy as a catalyst for educational change: $A$ background paper. Australia: Queenlands University of Technology.

Dale, L. E. (1989). Pedagogisk professionalitet. Olso: Gyldendal Norsk Forlag.

Dewey, B. I. (2004). The embedded librarian: Strategic campus collaborations. Resource Sharing \& Information Networks, 171), s. 5-17.

Dixon-Thomas, C. (2012). Information literacy and the 21st century academic librarian: A delphi study(Ph.D.). Available from ProQuest Dissertations \& Theses Global. Retrieved from http://search.proquest.com/docview/922671414

Duus, G., Husted, M., Kildedal, K., Laursen, E. \& Tofteng, D. (red.) (2012). Aktionsforskning : En grundbog. Frederiksberg: Samfundslitteratur.

Ford, P. J., Foxlee, N. \& Green, W. (2009). Developing information literacy with first year oral health students. European Journal of Dental Education, 13(1), s. 4651.

Gibson, S. \& Luxtin, J. (2009). Departure from the library desk! one undergraduate programme's story of its subject librarian's evolving role. SCONUL FocUS, 45, s. 41-44.

Hastrup, K., Rubow, C. \& Tjørnhøj-Thomsen, T. (2011). Kulturanalyse: Kort fortalt. Frederiksberg: Samfundslitteratur.

Henricson, M. (red.). (2014). Videnskabelig teori og metode: Fra idé til eksamination. København: Munksgaard.

Hummelvoll, J. K. \& Severinsson, E. (2005). Researchers' experience of co-operative inquiry in acute mental health care. Journal of Advanced Nursing, 52(2), s. 180188.

Hummelvoll, J. (2006). Handlingsorienteret forskningssamarbejde. Norsk Tidsskrift for Sygeplejeforskning, 1, s. 17-30.

Jungk, R. \& Müllert, N. R. (1989). Håndbog i fremtidsværksteder(2nd ed.).

København: Politisk revy.

Kirketerp, A. \& Greve, L. (2011). Entreprenørskabsundervisning. Århus: Aarhus Universitetsforlag.

Kotter, J. P. (1996). Leading Change. Boston, Mass.: Harvard Business School. 
Kvale, S. \& Brinkmann, S. (2009). Interview: Introduktion til et håndværk (2. udgave). København: Hans Reitzels Forlag.

Leth Andersen, H. (red.) (2009). Informationskompetence i udvikling. Århus: Center for Undervisningsudvikling, Aarhus Universitet.

Malterud, K. (2013). Kvalitative metoder i medisinsk forskning - en innføring (3rd ed.). Oslo: Universitetsforlaget.

McCluskey, C. (2010). Learning and teaching in action. beyond the library: Reflections from a librarian in an academic faculty. Health Information \& Libraries Journal, 273), s. 249-252.

McNiff, J. (2013). Action Research : Principles and Practice (3rd ed.). London: Routledge.

Morgan, D. L. (1997). Focus Groups as Qualitative Research (2nd ed.). Thousand Oaks, Calif.: Sage.

Moselen, C. \& Wang, L. (2014). Integrating information literacy into academic curricula: A professional development programme for librarians at the University of Auckland. Journal of Academic Librarianship, 40(2), s. 116-123.

Pålshaugen, $\emptyset$. (1991). Som sagt, så gjort?: Språket som virkemiddel $i$ organisasjonsutvikling og aksjonsforskning. Oslo: Novus.

Pettersen, R. (1997). Problemet først: Problembaseret læring som pædagogisk idé og strategi. Oslo: Tano Aschehoug.

Rienecker, L. \& Stray Jørgensen, P. (2012). Den gode opgave: Håndbog i opgaveskrivning på videregående uddannelser(4. udgave ed.). Frederiksberg: Samfundslitteratur.

Secker, J. (2011). A new curriculum for information literacy. Transitional, transferable, transformational. Cambridge: Cambridge University. Retrieved from http://ccfil.pbworks.com/f/Executive_summary.pdf

Torras, M. \& Sætre, T. P. (2009). Information Literacy Education - a Process Approach : Professionalising the Pedagogical Role of Academic Libraries. Oxford: Chandos Publishing.

Uddannelses- og forskningsministeriet (2013). Niveauer i kvalifikationsrammen. Retrieved from http://ufm.dk/uddannelse-og-institutioner/anerkendelse-ogdokumentation/dokumentation/kvalifikationsrammer/niveauer-ikvalifikationsrammen

Waldstrøm, C. med Engelbrecht, B. (2013). Ledelse af netværk: Virksomhedens skjulte ressource (2nd ed.). Kbh.: L\&R Business.

Wang, X. (2010). Integrating information literacy into higher education curricula. An IL curricular integration model. Faculty of Science technology, Queensland University of technology, Australia.

Whitehurst, A. P. (2010). Information literacy and global readiness: Library involvement can make a world of difference. Behavioral \& Social Sciences Librarian, 29(3), s. 207-232. 